\title{
Relationship of the species Commiphora leptophloeos with aedes aegypti: a review
}

\author{
Relação da espécie Commiphora leptophloeos com aedes aegypti: uma revisão \\ Relación de la especie Commiphora leptophloeos con aedes aegypti: una revisión
}

Received: 02/07/2022 | Reviewed: 02/14/2022 | Accept: 02/23/2022 | Published: 03/04/2022

\author{
Joélio Pereira da Silva \\ ORCID: https://orcid.org/0000-0002-8182-2000 \\ State University of Ceará, Brasil \\ E-mail: joeliops@hotmail.com \\ Eridan Orlando Pereira Tramontina Florean \\ ORCID: https://orcid.org/0000-0002-5033-8670 \\ State University of Ceará, Brasil \\ E-mail: eridanpereira@gmail.com \\ Rondenelly Brandão Silva \\ ORCID: https://orcid.org/0000-0002-6004-2478 \\ Floriano College, Brasil \\ E-mail: rondenelly@gmail.com \\ Yara Duarte Santos \\ ORCID: https://orcid.org/0000-0002-9697-6213 \\ Floriano College, Brasil \\ E-mail: yaradusantos16@hotmail.com \\ Murilo Madelman Silva Pereira \\ ORCID: https://orcid.org/0000-0002-4837-7267 \\ Floriano College, Brasil \\ E-mail: murilomadelman.bio@gmail.com \\ Laryssa Roque da Silva \\ ORCID: https://orcid.org/0000-0002-6701-0268 \\ State University of Piauí, Brasil \\ E-mail: laryssaroqueds@gmail.com
}

\begin{abstract}
Commiphora leptophloeos (Burseraceae) is a plant belonging to the genus Commiphora popularly known as imburana or umburana. It found in the caatinga and cerrado of Brazil. The species belonging to the genus Commiphora are used in folk medicine as anti-inflammatory, antimicrobial and in the treatment of several diseases. In recent decades, cases of diseases caused by the Aedes aegypti mosquito have increased considerably, making it necessary to seek alternative measures to combat the vector. The present study aimed to analyze, through bibliographic review, Commiphora leptophloeos regarding aspects of family, genus and species; and describe the relationship of this species with Aedes aegypti, highlighting natural products in the control. The findings indicate repellent activity of species of the genus Commiphora on insects, in addition to the presence of some mono and sesquiterpenes compounds, widely distributed in the genus, among them $\alpha$-pinene, camphene and $\beta$-pinene. Studies also confirm the ethnobotanical uses of $C$. leptophloeos, as well as its potential in the treatment of diseases. The analyzed literature indicates the antimicrobial activity of the aqueous extract of the bark and stem of C. leptophloeos against Staphylococcus epidermidis. Other data reveal that the essential oil of this species has larvicidal and deterrent activity against $A$. aegypti. The revised literature suggests the importance of natural products, their advantages as biopesticides, as well as the effectiveness of $C$. leptophloeos in combating the A. aegypti mosquito, stressing the need for further studies and tests to isolate the compounds present in this species.
\end{abstract}

Keywords: Commiphora leptophloeos; Aedes aegypti; Control; Natural products; Biopesticide; Repellent activity.

\section{Resumo}

Commiphora leptophloeos (Burseraceae) é uma planta pertencente ao gênero Commiphora e é conhecida popularmente como imburana ou umburana. É encontrada na caatinga e cerrado do Brasil. As espécies pertencentes ao gênero Commiphora são utilizadas na medicina popular como anti-inflamatórios, antimicrobianos e no tratamento de diversas doenças. Nas últimas décadas, os casos de doenças causadas pelo mosquito Aedes aegypti aumentaram consideravelmente, tornando necessário buscar medidas alternativas de combate ao vetor. O presente trabalho teve como objetivo analisar por meio de revisão bibliográfica a Commiphora leptophloeos quanto aos aspectos da família, gênero e espécie; e descrever a relação desta espécie com o Aedes aegypti, destacando os produtos naturais no controle. Os achados apontam atividade repelente de espécies do gênero Commiphora sobre insetos, além da presença de compostos mono e sesquiterpenos, distribuídos amplamente no gênero, dentre eles $\alpha$-pineno, canfeno e $\beta$-pineno. Estudos confirmam também os usos etnobotânicos de C. leptophloeos, como o seu potencial no tratamento 
de doenças. A literatura analisada indica a atividade antimicrobiana do extrato aquoso da casca e do caule de Commiphora leptophloeos contra Staphylococcus epidermidis. Outros dados revelam que o óleo essencial desta espécie apresenta atividade larvicida e deterrente frente A. aegypti. A literatura revisada sugere a importância dos produtos naturais, suas vantagens como biopesticidas, bem como a efetividade de Commiphora leptophloeos no combate ao mosquito A. aegypti, salientando a necessidade de outros estudos e testes, para isolar os compostos presentes nesta espécie.

Palavras-chave: Commiphora leptophloeos; Aedes aegypti; Controle; Produtos naturais; Biopesticida; Atividade repelente.

\begin{abstract}
Resumen
Commiphora leptophloeos (Burseraceae) es una planta perteneciente al género Commiphora conocida popularmente como imburana o umburana. Se encuentra en la caatinga y el cerrado de Brasil. Las especies pertenecientes al género Commiphora se utilizan en la medicina popular como antiinflamatorio, antimicrobiano y en el tratamiento de diversas enfermedades. En las últimas décadas, los casos de enfermedades causadas por el mosquito Aedes aegypti han aumentado considerablemente, por lo que es necesario buscar medidas alternativas para combatir el vector. El presente trabajo tuvo como objetivo analizar, a través de una revisión bibliográfica, Commiphora leptophloeos en cuanto a aspectos de familia, género y especie; y describir la relación de esta especie con Aedes aegypti, destacando los productos naturales en el control. Los hallazgos muestran actividad repelente de especies del género Commiphora sobre insectos, además de la presencia de algunos compuestos mono y sesquiterpénicos, ampliamente distribuidos en el género, entre ellos $\alpha$-pineno, canfeno y $\beta$-pineno. Los estudios también confirman los usos etnobotánicos de $C$. leptophloeos, como su potencial en el tratamiento de enfermedades. La literatura analizada indica la actividad antimicrobiana del extracto acuoso de corteza y tallo de C. leptophloeos frente a Staphylococcus epidermidis. Otros datos revelan que el aceite esencial de esta especie tiene actividad larvicida y disuasoria contra A. aegypti. La literatura revisada sugiere la importancia de los productos naturales, sus ventajas como bioplaguicidas, así como la efectividad de C. leptophloeos en el combate del mosquito A. aegypti, destacando la necesidad de más estudios y pruebas para aislar los compuestos presentes en esta especie.
\end{abstract}

Palabras clave: Commiphora leptophloeos; Aedes aegypti; Control; Productos naturales; Biopesticida; Actividad repelente.

\title{
1. Introduction
}

The use of medicinal plants as a therapeutic option is of great importance for maintaining people's health conditions, especially for the low-income population. According to Brasil (2004) the difference between medicinal plant and herbal medicine lies in the fact that to be considered a herbal medicine, a specific formulation of the medicinal plant must be elaborated. In addition to proving the therapeutic action of various plants used popularly, phytotherapy represents an important part of the culture of a people, and is also part of a knowledge used and disseminated by populations over several generations (Brasil, 2004).

Observation of the behavior of animals and the empirical verification of the effects of eating vegetables on the human organism played an important role in discovering the cure of diseases through medicinal plants. This popular practice has contributed to scientific research and dissemination of therapeutic properties, validating or not the use of certain medicinal plants (Tomazzoni et al., 2006).

It is noteworthy that the environmental conditions of the semi-arid determined a unique vegetation, with elements that express anatomy, morphology and physiological mechanisms appropriate to local conditions, usually with low and twisted trees and shrubs, with dry appearance, with small leaves and deciduous and roots very developed, thick and penetrating. Thus, a large part of the caatinga plant species is used in the supply of edible fruits, fodder, firewood, coal, wood for the construction of fences, carpentry, handicrafts and other uses (Sampaio, 2002).

In general, nature produces most of the known organic substances, with secondary metabolites being the compounds that played a fundamental role in the development of modern synthetic organic chemistry. These organic compounds, in turn, can potentially be studied for the development of drugs of natural origin or even bioinsecticides less toxic to mammals and the environment. 
In order to know, protect and sustainably use the natural resources of the vegetation of the Caatinga biome, it is necessary to increase the number of floristic and phytosociological surveys, on a continuous and regular basis. Knowing the Caatinga, it will be possible, then, to establish actions that preserve its genetic heritage and its use in a rational way, in order to promote economic return (Araújo Filho et al., 1997).

The species Commiphora leptophloeos (Mart.) J.B. Gillet (Burseraceae) is one of the most representative species of the Caatinga biome popularly known as imburana-de-cambão, imburaninha or imburana-de-espinho. Presents decisiveness, with heliophile, pioneer and xerophilic behavior. It is worth mentioning that this Brazilian species is not endemic to the Caatinga, being, for example, also found in Goiás State, Brazil; which has Cerrado Biome predominately (Silva et al., 2004).

For Lima (2010) the species C. leptophloeos presents different functional and phenological aspects, such as, for example, mechanisms of flowering and fruiting during the dry season. These aspects are considered of great importance for the maintenance of populations of pollinators and seed dispersers, which need resources during the period when food is scarce. It can be used for revegetation of the Caatinga, as it has fast growth and few requirements, as well as extinction risk due to the slow development and limited amount of seeds.

Thus, the relevance of this study lies in the fact that it contributes to the rescue and maintenance of the traditional botanical knowledge of the Caatinga in northeastern Brazil, the popular knowledge about plants and their uses, in addition, the information described here will serve as a basis for new studies to be carried out in communities and ecosystems associated with the Caatinga biome.

In this context, the objective of the present study was to analyze, by means of bibliographic review, Commiphora leptophloeos regarding aspects of family, genus and species; and describe the relationship of this species with Aedes aegypti, highlighting natural products in the control.

\section{Methodology}

The present study uses as a method the narrative review of the descriptive literature, which aims to gather and concentrate the scientific knowledge already produced on the relationship of the species Commiphora leptophloeos with Aedes aegypti through the use of active methodologies, providing the opportunity to search and the synthesis of evidence contained in the literature to contribute to the development of knowledge on the subject. The general objective of a narrative review of research literature is to gather knowledge about a subject, in order to support a meaningful study for nursing, being considered one of the best ways to start a study, where one looks for the similarities and differences in the articles found (de Sousa LMM et al 2017; Souza, Silva \& Carvalho, 2010).

\section{Results and Discussion}

The results were divided into Commiphora leptophloeos and Aedes aegypti in order to inform about the species and use that knowledge to relate them

\subsection{Commiphora leptophloeos}

\subsubsection{The Burseraceae family}

The Burseraceae family has about 750 species in 19 genera, with a pantropical distribution. It makes up an important part of the wet and dry forests of many parts of the tropics, and because they have resinous channels in their bark, they are known as a source of resins. The family is divided into the Canarieae, Protieae and Bursereae tribes and belongs to the order Sapindales (Daly et al., 2012). 
The hydrophobic resins exuded from the bark of several species of Burseraceae are commonly used as components in the preparation of varnishes and are known as Elemi. The Protium genus is one of the most heterogeneous in the family and its resins are used in folk medicine to heal wounds, as antiseptics, and smoke inhalation as an analgesic (Rüdiger, Siani \& Junior, 2007).

In this sense, some reigns found in the family also have a hydrophilic character, Myrrh of the genus Commiphora and Frankincense (incense) of the genus Boswellia are resin products used in medicine and cosmetics (Shen T et al., 2012). In Lebanon, for example, the incense obtained from Boswellia neglecta and B. ogadensis, the myrrh obtained from Commiphora myrrha, C. truncata and C. borensis and the agar obtained from C. africana, contribute to about $32.6 \%$ of the annual income of families, being in second place, after the livestock in the general domestic support (Lemenih et al., 2003).

\subsubsection{The genus Commiphora}

The genus Commiphora Jacq. it has about 190 species, approximately 150 species of African origin distributed in the desert and in dry regions. Outside the African continent, its distribution occurs in similar environments such as Madagascar, the Middle East, India, Siri Lanka and South America (Weeks et al., 2007).

According to Becerra (2003) phylogenetic analyzes suggest that Bursera is a monophyletic genus closely related to the genus Commiphora. The author suggests the need to evaluate the differences between both genders, indicating the presence of Commiphora in South America and transferring Bursera leptophloeos to Commiphora leptophloeos.

The gender transfer could be confirmed through phylogenetic analyzes using sequences from the ITS, 5S-NTS and ETS regions of nuclear ribosomal DNA, indicating that Bursera leptophloeos would actually be within the genus Commiphora (Becerra, 2003).

In this way, many exudates resins of the genus Commiphora are usually used as perfumes, incense or ointments, and their medicinal properties are also widely explored by traditional communities. Numerous secretory channels are found in the bark of trees of the genus, forming cavities from which resins flow from a wound. Myrrh, for example, is a resin produced by several species of the genus Commiphora. There are reports that myrrh was used in mummification processes, and burned inside temples to perfume mummies in Egypt (Langenheim, 2003; Latha et al., 2021).

According to the study by Shen et al., (2012) more than 300 molecules have already been identified for the genus, and among mono and sesquiterpenes, some compounds are widely distributed among species, such as $\alpha$-pinene, camphene, $\beta$ pinene, myrcene, limonene, $\beta$-elemene, $\alpha$-copene, germacrene B and others, commonly found in volatile oils (Figure 1). 
Figure 1 - Chemical structures of some compounds found in species of the genus Commiphora.

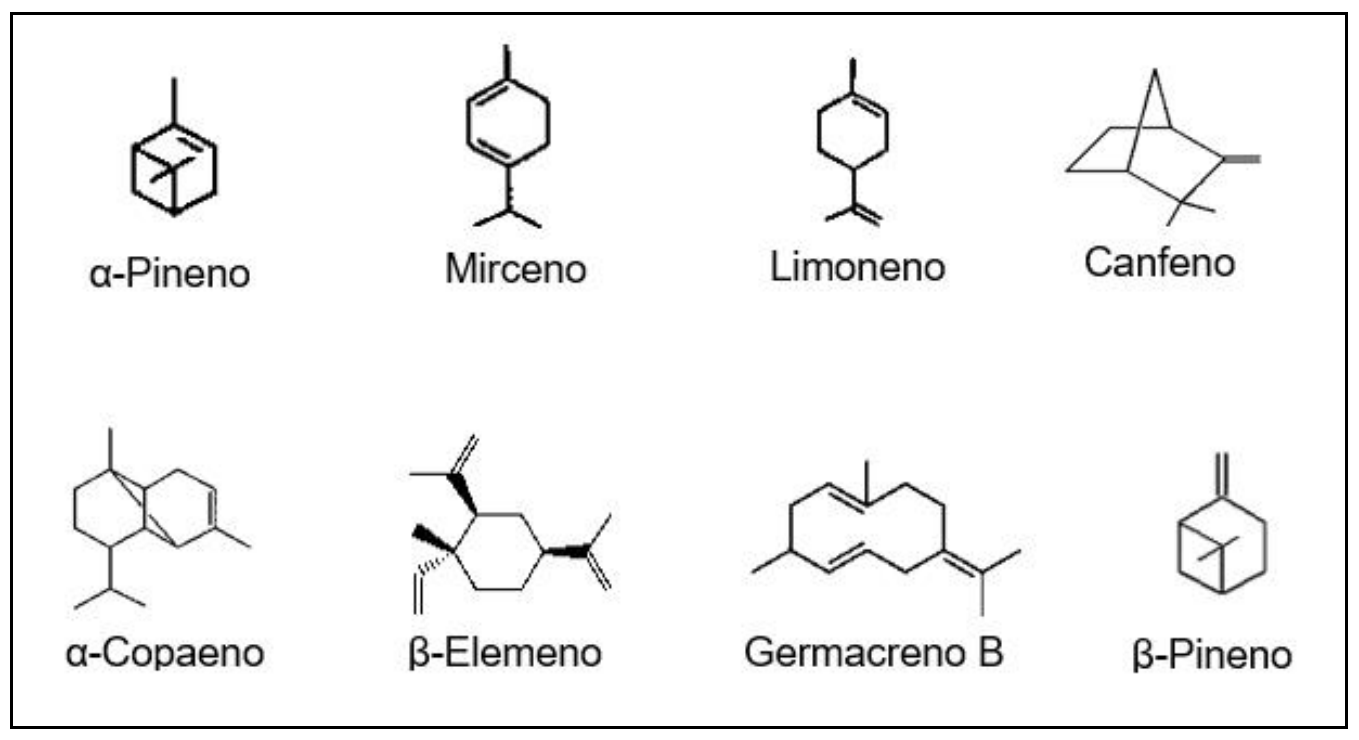

Source: Adapted from Revista Química Nova Escola (2017).

Thus, there are several medicinal uses of Commiphora species, among them: traditional uses such as in the treatment of pain, fractures, inflammation, rheumatism, infections, nasal congestion, sore throat, fever, pest repellent in animals; and pharmacological uses such as antitumor, anti-inflammatory, analgesic, antimicrobial, hypotensive, antiparasitic and others. In addition, in one of the studies developed, the anticancer, anti-inflammatory, antimicrobial, antioxidant and non-cytotoxic activity of several species of Commiphora that occur in South Africa was proven (Paraskeva MP et al, 2008).

\subsubsection{The species Commiphora leptophloeos (Mart.) JB Gillett}

Commiphora leptophloeos (Mart.) J.B.Gillett, popularly known as Imburana or Umburana, is a deciduous angiosperm, occurring in the caatinga and cerrado of Brazil, belonging to the Burseraceae family. Its use for the restoration of degraded areas contributes to meliponiculture, in addition to being widely used for medicinal purposes. Through the decoction of its bark, a syrup is produced, used in the treatment of flu, coughs and bronchitis (Maia-Silva C et al, 2012; Agra MDF et al., 2007).

Regarding the botanical description, the biological form and seasonality is arboreal (tree-shaped), of deciduous behavior. Larger trees reach dimensions close to $12 \mathrm{~m}$ in height and $60 \mathrm{~cm}$ in DBH (diameter at breast height, measured at 1.30 $\mathrm{m}$ from the ground), in adulthood (Figure 2a). Trunk: it is tortuous and very tufted, with sharp and strong spines. The branch is jerky. The canopy is wide and irregular. Its bark measures up to $0.63 \mathrm{~cm}$ thick, where the outer bark or rhytidoma is smooth, glossy, loosening into thin, revolute, very irregular and characteristic blades (Figure 2b). However, the characteristic bark should not be confused with that of the coumaru (Amburana cearensis), devoid of thorns and with a strong coumarin smell (Carvalho, 2009). 
Figure 2 - Commiphora leptophloeos (Mart.) JB Gillett: A (adult tree); B (stem).

A

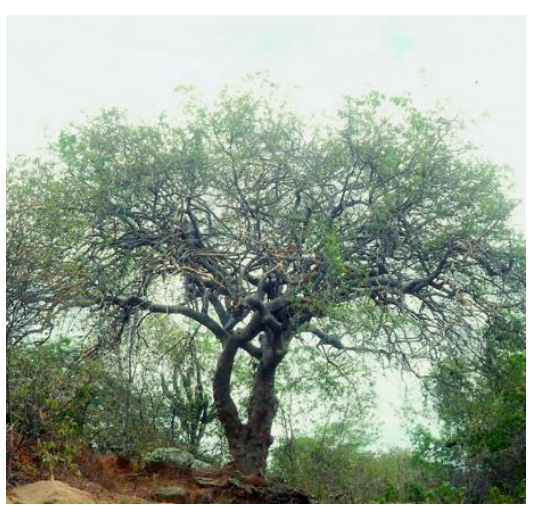

B

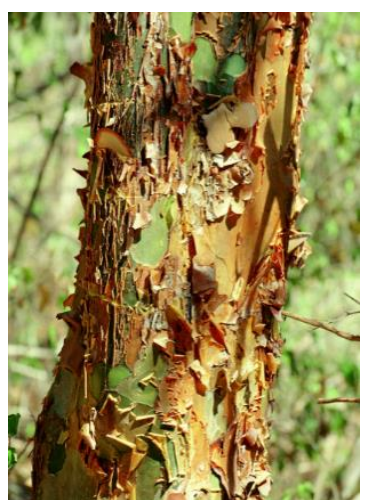

Source: Northeast Plant Database (2008).

The leaves are alternate, pale green-pink when very young, composed, dispassionate, with three to nine oval leaflets, measuring $1.5 \mathrm{~cm}$ to $3.5 \mathrm{~cm}$ long, whole at the margin, with a slight resin smell when bruised (Figure 2a). The inflorescence presents itself in axillary panicles, where the flowers are small, measuring from $3 \mathrm{~mm}$ to $4 \mathrm{~mm}$ in length, of a very light green color, isolated or gathered in small groups (Figure 2b) (Carvalho, 2009).

Its fruit is a phyllotrimid drupid, green in color, measuring about $1.5 \mathrm{~cm}$ in diameter (Figure 2a). Under heat stroke, the fruit opens in the middle, releasing a single seed. The seed is rigid, rough, with a diameter greater than $1 \mathrm{~cm}$, black - except at the base, where it becomes white, covered at the base by a red aryl (Carvalho, 2009).

Figure 3 - Commiphora leptophloeos (Mart.) JB Gillett: A (inflorescence); B (leaves and fruits).
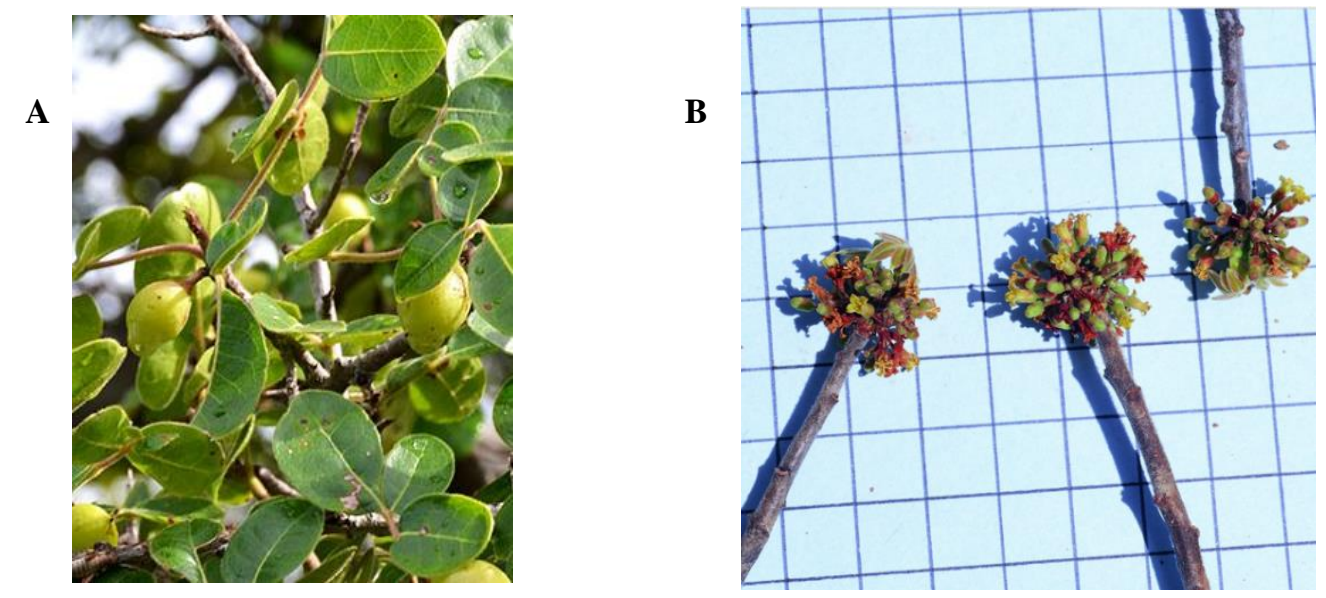

Source: Northeastern Plant Information Center (2008).

Several studies report on the ethnobotanical uses of C. leptophloeos, such as its potential in the treatment of diseases such as flu, cough, bronchitis, stomach pain, kidney problems, inflammation in general, colic, diarrhea, toothache, dysphonia and other applications (Ferreira Júnior et al., 2011).

Thus, among the forms of preparation used are decoction and syrup, to ingest or pass over the affected area, and the bark and stem are among the most used parts of the plant (Cartaxo et al., 2010). For Lucena et al., (2012) in the community of Barrocas and Cachoeira, Paraíba-Brazil, they observed that C. leptophloeos was among the plants with the highest value for general use, with citations for the medicinal, veterinary, technological, construction and fuel categories. 
According to the study by da Silva Trentin et al., (2011) the antimicrobial activity against Staphylococcus epidermidis from the aqueous extract of the bark and stem of C. leptophloeos was proven, obtaining one of the lowest rates of biofilm formation and no bacterial growth in the growth test planktonic at $4 \mathrm{mg} / \mathrm{mL}$ among the plants studied.

The study by Coutinho HD et al., (2009) demonstrated that the Nasutitermes corniger extract when grown on $C$. leptophloeos had a synergistic or additive effect with the antibiotic gentamicin and neomycin reduced to MIC in the fight against Escherichia coli, showing the importance of the substrate of growth in the antimicrobial activity of $N$. corniger.

It should be noted that $C$. leptophloeos is characterized by the low density of the wood, succulent stem and flowering during the dry season, being considered of secondary ecological succession and difficult to propagate, due to the low seed production (Maia, 2012).

The spread of imburaninha can be done by seeds, however, they show intermittent germination and with low percentages. The species has good ability to regrowth, making it suitable for hedges, with no need to replace the old cuttings with new ones (Maia, 2012).

According to Lima (2010), this species has different functional and phenological aspects, such as mechanisms of flowering and fruiting during the dry season. These aspects are considered of great importance for the maintenance of populations of pollinators and seed dispersers, which need resources during the period when food is scarce. It can be used for revegetation of the Caatinga, as it has fast growth and few requirements, as well as extinction risk due to the slow development and limited amount of seeds.

In addition, the species is fundamental to the balance of the ecosystem, as it provides pollen and nectar to bees. Generally, their trees have cavities in their trunks and branches, which allows native bees to nest. Thus, the imburana-decambão is considered the most used species for the construction of nests (de Novais et al., 2010).

Finally, Leite et al. (2009) corroborate it by pointing out that another use attributed to this species is its application as a raw material for the handmade production of religious sculptures, because the wood of the imburaninha is light and homogeneous, which makes it suitable for artisans who use it in the production of sculptures.

\subsection{Aedes aegypti}

The occurrence of Aedes aegypti was first described in Egypt by Linnaeus, in 1762, with the mosquito being present in the tropics and subtropics - in practically the entire American continent, in Southeast Asia, and throughout India. It is suspected that the introduction of this species in Brazil occurred in the colonial period, between the 16th and 19th centuries, during the slave trade (Consoli \& Oliveira, 1994). With the destruction of natural habitats, due to anthropic pressures, part of the wild population underwent a selective process that favored the spread and survival of the species in human settlements.

The ethology of A. aegypti benefits from its wide dispersion, favored in urban environments, preferably in the intra and peridomicile areas. They are rarely found in semi-wild environments or where there is no intense presence of man. Its preferred breeding sites are artificial containers, both those abandoned in the open, which serve as a rainwater reservoir, as well as those used to store water for domestic use. The presence of breeding sites in an environment of interaction with man favors the rapid proliferation of the species, for two aspects: ideal conditions for reproduction and sources of food.

A. aegypti is a mosquito of great epidemiological importance as it is the known vector of dengue and yellow fever. It is distributed in tropical and subtropical areas of the globe, being the main vector of the four serotypes of the dengue virus.

About 2.5 billion people are at risk of contracting diseases transmitted by A. aegypti. Among these diseases, it is estimated that approximately 50 million people are infected annually in more than 100 countries by dengue alone, with an estimated 500,000 people being infected with severe cases and $2.5 \%$ of these cases being led to death (WHO, 2012). 
The temperature and the climatic factor are preponderant for its development, where the pluviometric precipitation acts directly on the mosquito abundance by increasing the density of artificial breeding sites. Because it is an anthropophilic mosquito, the places with the highest incidence are where there is the greatest human concentration, where environments are conducive to their reproduction (Beserra et al., 2006).

For Silva and Silva (1999) the adaptations of A. aegypti allowed them to become abundant in cities and to be easily taken to other areas by means of transport, which increased their vectorial competence, that is, their ability to become infected by a virus, replicate and transmit it.

The female is able to make multiple ingestions of blood during a single gonadotrophic cycle, which increases her ability to become infected and to transmit viruses. This behavior makes $A$. aegypti an efficient vector. The quiescence of eggs allows the maintenance of the cycle in nature during seasonal climatic variations, since the viability of $A$. aegypti eggs reaches up to 492 days in the dry season, hatching after contact with water (Carvalho et al., 2014).

With regard to oviposition behavior, the Aedini, a tribe that contemplates the genus Aedes, have a different behavior from other culicids, depositing their eggs near water or in potentially flooded places. This characteristic allows their eggs deposited out of the water to have the ability to enter a quiescent state before being flooded (Foster et al., 2019).

\subsubsection{Control programs for A. aegypti in Brazil}

As of 1996, the Ministry of Health put into practice the A. aegypti Eradication Plan (PEAa), which advocated multisectoral action and provided for a decentralized model with the participation of the three spheres of government, whose main objective was to in reducing cases of hemorrhagic dengue. Even with efforts to structure the fight against the vector in the municipalities, the PEAa did not achieve the necessary multisectoral action, which can be pointed out as one of the factors responsible for the failure to contain the increase in the number of dengue cases and for the advance of the disease infestation of A. Aegypti (Braga et al., 2007; Brasil, 2009).

Thus, in 2001, the government gave up the goal of eradicating the mosquito and started to consider vector control, with the implementation of the Intensification Plan for Dengue Control Actions (PIACD), prioritizing actions in municipalities with greater transmission of dengue. In 2002, the National Dengue Control Plan (PNCD) was developed due to the increased risk of epidemics, the occurrence of serious cases of dengue and the reintroduction and rapid spread of serotype 3 in the country (Figueiró et al., 2010).

Due to the absence of vaccines available for the prevention of diseases transmitted by A. aegypti, the measures for combating and monitoring are aimed at eliminating the vector. In this way, three lines are used: environmental sanitation, educational activities to reduce breeding sites and direct combat through chemical, physical and biological agents. Entomological surveillance aims, among other factors, to monitor the presence of the vector, infestation rates and the efficiency of control methods, mapping risk areas (Braga et al., 2007; Juarez et al., 2021).

Thus, with the support of the Ministry of Health and the states, the municipal health departments started to manage and execute the PNCD actions, which involved ten main components: epidemiological surveillance, combating the vector, patient care, integration with primary care, environmental sanitation actions, integrated health education actions, communication and social mobilization, human resources training, legislation, political and social support and monitoring and evaluation of the PNCD (Brasil, 2002).

It turns out, then, that the Program is no longer exclusively aimed at combating the vector and suggested adjustments consistent with local specificities, including the possibility of preparing sub-regional plans.

It should also be noted that in Brazil, Community Health Agents (ACS) and Endemic Combat Agents (ACE), in partnership with the population, are responsible for promoting the mechanical and chemical control of the vector, whose 
actions are centered on detect, destroy or properly dispose of natural or artificial water reservoirs that can serve as deposits for Aedes eggs. Another complementary strategy advocated by the Ministry of Health is the promotion of educational actions during home visits by Community Agents, with the aim of ensuring the sustainability of the elimination of breeding sites by property owners, in an attempt to break the chain of disease transmission (Brasil, 2009).

It is noteworthy that, in this task, it is possible to use basically three types of control mechanisms: mechanical, biological and chemical. Mechanical control consists of adopting practices capable of eliminating the vector and breeding sites or reducing the contact between mosquitoes and humans. The main mechanical control activities involve the protection, destruction or proper destination of breeding sites, drainage of reservoirs and installation of screens on doors and windows (Manrique-Saide et al., 2015).

Biological control is based on the use of predators or pathogens with the potential to reduce the vector population. Among the available alternatives for predators are fish and aquatic invertebrates, which eat larvae and pupae, and pathogens that release toxins, such as bacteria, fungi and parasites (Shulse et al., 2013).

Whereas, chemical control consists of using chemicals, which can be neurotoxic, juvenile hormone analogs and chitin synthesis inhibitors, to kill adult larvae and insects. It is a type of control recommended through rational and safe use for the environment and for the population, complementary to the actions of surveillance and environmental management, due to the possibility of selecting vectors resistant to the products and the generation of environmental impacts (Braga et al., 2007).

Methoprene is the most used and recommended by the World Health Organization for the control of A. aegypti, its action acts in inhibiting the emergence of adults and can be a good alternative since it is accompanied by a field assessment capable of estimating larval density (Braga et al., 2007). Biological control with organisms capable of predating or parasiting mosquitoes or any of their phases has also been studied. The bacterium Bacillus thuringiensis israelensis has a high larvicidal activity due to the production of some toxins that destroy the larval stomach epithelium leading to death (Consoli et al., 1994).

\subsection{Commiphora leptophloeos natural products for the control of Aedes aegypti}

As an alternative to chemical control, some natural compounds, such as essential oils from plants, have been investigated for evidence of larvicidal activity against A. aegypti. The characteristics of certain structural chemical groups of these compounds or the combination between them can confer an increase or reduction in larvicidal activity (Pereira et al., 2014; Rocha, et al., 2022).

However, it is important to note that, in addition to the larvicidal effect, these new compounds must demonstrate a prolonged residual effect in the deposits where they are applied. This is an important characteristic for the adoption of a certain compound in public health campaign activities.

In order to mitigate the proliferation of mosquitoes, insecticides and capture traps have been used, but the emergence of strains resistant to insecticides and larvicides has proved to be one of the main obstacles with regard to their control. This resistance results in an increased frequency of application and an increase in dosages, which may reflect on side effects on plants, humans and environmental damage (Simas et al., 2004).

Tests carried out by Navarro et. al., 2003 revealed that the essential oil of Commiphora leptophloeos has larvicidal activity against $A$. aegypti. The study was carried out using an adaptation of the method recommended by the World Health Organization (WHO, 2003). Thus, larval mortality was determined after 48 hours of incubation at $27 \pm 0.5^{\circ} \mathrm{C}$. Larvae were considered dead when they did not respond to stimuli or did not rise to the surface of the solution. The promising results demonstrated LC50 at a concentration of 99.4 ppm (Autran et al., 2009).

According to Simões (1999), terpenoid derivatives commonly constitute the majority of essential oil compounds, with monoterpenes and sesquiterpenes being the most frequent classes. The composition of essential oils varies widely between 
species of Commiphora. Among the monoterpenes $\alpha$-Pineno, Canfeno, $\beta$-Pineno, Mirceno and Limoneno have already been found. Among sesquiterpenes, compounds such as $\beta$-Elemene, $\alpha$-Copaeno, $\alpha$-Humulene, $\beta$-Selinene and Germacrene B are widely distributed among different species of the genus Commiphora (Shen et al., 2012).

The behavioral tests to evaluate the deterrent activity of oviposition of the essential oil of C. leptophloeos against pregnant females of $A$. aegypti, showed that this essential oil was significantly active in concentrations of 100,50 and $25 \mathrm{ppm}$, presenting a smaller number of eggs left in the containers containing the test solutions compared to the control solution (Khandagle et al., 2011).

Thus, it is verified based on the reviewed literature, that the deterrent action of the essential oil of C. leptophloeos is able to inhibit by about $63 \%$ the amount of eggs deposited in the container containing the test solution at a concentration of 25 ppm.

In this sense, Bissinger \& Roe (2010) state that some species of Commiphora are pointed out for presenting insect repellent activity. C. erythreae, C. holtziana and C. swynnertonii have repellent activity against different tick species. However, the analysis of the influence on the oviposition behavior of the essential oil of Commiphora species on diseasecarrying mosquitoes is scarce, making it difficult to evaluate comparative studies.

Campbell et al., (2011) analyzed in their studies the electrophysiological responses of A. aegypti to various essential oils by gas-chromatographic-electroantenographic detection (GC-EAD), during the period of searching for food. The result demonstrated the detection of 42 components, including $\alpha$-Felandreno, $\alpha$-Pineno and $\beta$-Pineno, $\alpha$-Terpineol and Germacreno $\mathrm{D}$, compounds present in the oil of $\mathrm{C}$. leptophloeos. Trans-Karyophylene has also been described to stimulate the antennae of A. aegypti, a compound that is part of the oil of C. leptophloeos and which also stimulated the antenna of pregnant females of A. aegypti.

It is noteworthy that the deterrent activity of $C$. leptophloeos oil can be attributed to its presence in a significant proportion in the oil or the synergistic activity of this compound with other constituents present in the oil, such as $\alpha$-Humulene, which also presented a deterrent response significant at a concentration of $5 \mathrm{ppm}$. Both were able to repel the number of eggs in the test container by $60 \%$ and $70 \%$ respectively. In this context, because it is a widely distributed compound and induces a deterrent behavior towards the oviposition of $A$. aegypti, trans-Karyophylene can be considered an accessible alternative to combat mosquitoes, as well as $\alpha$-Humulene (Galdino et al., 2012).

\section{Final Considerations}

The great social and economic dependence of the Northeast region of Brazil in relation to the forest resources of the caatinga is associated with the supply of wood and non-wood products that this vegetation provides.

The essential oil of Commiphora leptophloeos leaves is rich in compounds derived from terpenoids and has compounds clearly recognized by pregnant women of A. aegypti through CG-DEA. The essential oil has deterrent oviposition activity between concentrations of 100 to $25 \mathrm{ppm}$, and $\alpha$-Humulene and trans-Karyophylene have been confirmed in the literature, as active ingredients of this oil, and can be used in oviposition sites to inhibit oviposition of A. aegypti female. In addition, the essential oil also showed potential larvicide, which can help control the spread of mosquitoes in urban areas.

Thus, it is possible to highlight the effectiveness of natural products and their advantages as biopesticides, as they are rapidly degraded, obtained from renewable resources and demand low production costs, becoming an important line of combat against $A$. aegypti.

It should also be noted that the control of dengue points to the need for greater investments in appropriate methodologies, to sensitize the population about the need for behavioral changes that aim to control the vector, in addition to 
environmental management. For future works, its suggested that it should includ expanding the focus of rational vector control actions, to minimize the use of insecticides and, thus, ensure greater sustainability to the actions.

\section{References}

Araújo Filho, J. D., \& Carvalho, F. D. (1997). Desenvolvimento sustentável da caatinga. Embrapa Caprinos.

Autran, E. S., Neves, I. A., Da Silva, C. S. B., Santos, G. K. N., Da Câmara, C. A. G., \& Navarro, D. M. A. F. (2009). Chemical composition, oviposition deterrent and larvicidal activities against Aedes aegypti of essential oils from Piper marginatum Jacq. (Piperaceae). Bioresource technology, 100(7), 22842288 .

Agra, M. D. F., Baracho, G. S., Nurit, K., Basílio, I. J. L. D., \& Coelho, V. P. M. (2007). Medicinal and poisonous diversity of the flora of "Cariri Paraibano”, Brazil. Journal of ethnopharmacology, 111(2), 383-395.

Barnett, J. R. (2004). Langenheim, JH Plant resins: chemistry, evolution, ecology and ethnobotany.

Becerra, J. X. (2003). Evolution of Mexican Bursera (Burseraceae) inferred from ITS, ETS, and 5S nuclear ribosomal DNA sequences. Molecular phylogenetics and evolution, 26(2), 300-309.

Beserra, E. B., Castro-Junior, F.P., Dos Santos, J. W., Santos, T. S. \& Fernandes, C. R. M. (2006). Biology and thermal requirements of Aedes aegypti (L.) (Diptera: Culicidae) from four bioclimatic regions of Paraíba. Neotropical Entomology 35(6):853-860.

Bissinger, B. W., \& Roe, R. M. (2010). Tick repellents: past, present, and future. Pesticide biochemistry and physiology, 96(2), 63-79.

Braga, I. A., \& Valle, D. (2007). Aedes aegypti: histórico do controle no Brasil. Epidemiologia e serviços de saúde, 16(2), 113-118.

BRASIL. Fundação Nacional de Saúde. Programa Nacional de Controle da Dengue (PNCD). Brasília: Ministério da Saúde, 2002.

BRASIL. Ministério da Saúde. Agência Nacional de Vigilância Sanitária. Dispõe sobre o registro de medicamentos fitoterápicos. Brasília, 2004.

BRASIL. Ministério da Saúde. Secretaria de Vigilância em Saúde. Departamento de Vigilância Epidemiológica. Diretrizes nacionais para a prevenção e controle de epidemias de dengue. Brasília, 2009.

Campbell, C., Gries, R., \& Gries, G. (2011). Forty-two compounds in eleven essential oils elicit antennal responses from Aedes aegypti. Entomologia Experimentalis et Applicata, 138(1), 21-32.

Carvalho, P. E. R. (2009). Imburana-de-Espinho-Commiphora leptophloeos. Embrapa Florestas-Comunicado Técnico.

Carvalho, R. G., Oliveira, L. R., Braga, I. A. (2014). Updating the geographical distribution and frequency of Aedes albopictus in Brazil with remarks regarding its range in the Americas. Mem Inst Oswaldo Cruz, 109(6):787-96.

Cartaxo, S. L., de Almeida Souza, M. M., \& de Albuquerque, U. P. (2010). Medicinal plants with bioprospecting potential used in semi-arid northeastern Brazil. Journal of ethnopharmacology, 131(2), 326-342.

Consoli, R. A., \& Oliveira, R. L. D. (1994). Principais mosquitos de importância sanitária no Brasil. Editora Fiocruz.

Coutinho, H. D., Vasconcellos, A., Lima, M. A., Almeida-Filho, G. G., \& Alves, R. R. (2009). Termite usage associated with antibiotic therapy: enhancement of aminoglycoside antibiotic activity by natural products of Nasutitermes corniger (Motschulsky 1855). BMC Complementary and Alternative Medicine, 9(1), $1-4$

Daly, D. C. D. B., Fine, P. V. A., \& Martínez-Habibe, M. C. (2012). Burseraceae: a model for studying the Amazon flora. Rodriguésia, 63(1), 021-030.

da Silva Trentin, D., Giordani, R. B., Zimmer, K. R., Da Silva, A. G., Da Silva, M. V., dos Santos Correia, M. T., ... \& Macedo, A. J. (2011). Potential of medicinal plants from the Brazilian semi-arid region (Caatinga) against Staphylococcus epidermidis planktonic and biofilm lifestyles. Journal of Ethnopharmacology, 137(1), 327-335.

de Novais, J. S., e Lima, L. C. L., \& dos Santos, F. D. A. R. (2010). Bee pollen loads and their use in indicating flowering in the Caatinga region of Brazil. Journal of arid environments, 74(10), 1355-1358.

de Sousa, L. M. M., Marques-Vieira, C. M. A., Severino, S. S. P., \& Antunes, A. V. (2017). A metodologia de revisão integrativa da literatura em enfermagem. $N^{o} 21$ Série 2-Novembro 2017, 17.

do Nordeste, A. P. (2011). Centro Nordestino de Informações sobre Plantas. Planos de manejo florestal sustentado na Caatinga. Recife,[2011]. < http://www. cnip. org. br/planos_manejo. html>.

Felipe, L. O., \& Bicas, J. L. (2017). Terpenos, aromas e a química dos compostos naturais. Química Nova na Escola, 39(2), 120-130.

Ferreira Junior, W. S., Siqueira, C. F. Q., \& de Albuquerque, U. P. (2012). Plant stem bark extractivism in the Northeast semiarid region of Brazil: A new aport to utilitarian redundancy model. Evidence-based Complementary and Alternative Medicine, 2012.

Figueiró, A. C., Sóter, A. P., Braga, C., Hartz, Z. M. D. A., \& Samico, I. (2010). Análise da lógica de intervenção do Programa Nacional de Controle da Dengue. Revista Brasileira de Saúde Materno Infantil, 10, s93-s106. 
Foster, W. A., \& Walker, E. D. (2019). mosquitoes (Culicidae). In Medical and veterinary entomology (pp. 261-325). Academic press.

Fundação Nacional de Saúde. Programa Nacional de Controle da Dengue (PNCD). Ministério da Saúde; 2002. 32 p.

Galdino, P. M., Nascimento, M. V. M., Florentino, I. F., Lino, R. C., Fajemiroye, J. O., Chaibub, B. A., \& Costa, E. A. (2012). The anxiolytic-like effect of an essential oil derived from Spiranthera odoratissima A. St. Hil. leaves and its major component, $\beta$-caryophyllene, in male mice. Progress in NeuroPsychopharmacology and Biological Psychiatry, 38(2), 276-284.

Juarez, J. G., Chaves, L. F., Garcia-Luna, S. M., Martin, E., Badillo-Vargas, I., Medeiros, M.C.I., Hamer, G. L. (2021). Variable coverage in an Autocidal Gravid Ovitrap intervention impacts efficacy of Aedes aegypti control. Journal of Applied Ecology, 58, $2075-2086$.

Khandagle, A. J., Tare, V. S., Raut, K. D., \& Morey, R. A. (2011). Bioactivity of essential oils of Zingiber officinalis and Achyranthes aspera against mosquitoes. Parasitology research, 109(2), 339-343.

Lakatos, E. M., \& Marconi, M. D. A. (2001). Do trabalho científico. Atlas.

Latha, S., Selvamani, P., Prabha, T. (2021). Pharmacological uses of the plants belonging to the genus commiphora. Essential Journal on Cardiovascular \& Hematological agents, 101-117.

Leite, A. A. M., \& Neto, A. F. F. (2009). Conhecimento, inovação e sustentabilidade no setor tradicional: o caso dos artesãos de petrolina-pe. Revista Gestão Industrial, 5(ESPECIAL).

Lemenih, M., Abebe, T., \& Olsson, M. (2003). Gum and resin resources from some Acacia, Boswellia and Commiphora species and their economic contributions in Liban, south-east Ethiopia. Journal of Arid Environments, 55(3), 465-482.

Lima, A. L. A. (2010). Tipos funcionais fenológicos em espécies lenhosas da caatinga, Nordeste do Brasil (Doctoral dissertation, Tese (Doutorado). Recife, UFRPE).

Lucena, R. F. P. D., Soares, T. D. C., Vasconcelos Neto, C. F. A. D., Carvalho, T. K. N., Lucena, C. M. D., \& Alves, R. R. D. N. (2012). Uso de recursos vegetais da Caatinga em uma comunidade rural no Curimataú Paraibano (Nordeste do Brasil). Polibotánica, (34), $237-258$.

Maia, G. N. (2012). Caatinga: árvores e arbustos e suas utilidades (413p). Fortaleza: Print color.

Maia-Silva, C., Silva, C. D., Hrncir, M., Queiroz, R. D., \& Imperatriz-Fonseca, V. L. (2012). Guia de plantas visitadas por abelhas na Caatinga. Fortaleza: Fundação Brasil Cidadão, 196.

Manrique-Saide, P., Che-Mendoza, A., Barrera-Perez, M., Guillermo-May, G., Herrera-Bojorquez, J., Dzul-Manzanilla, F., \& Arredondo-Jimenez, J. I. (2015). Use of insecticide-treated house screens to reduce infestations of dengue virus vectors, Mexico. Emerging infectious diseases, 21 (2), 308.

Navarro, D. M. A. F., De Oliveira, P. E. S., Potting, R. P. J., Brito, A. C., Fital, S. J. F., \& Sant'Ana, A. G. (2003). The potential attractant or repellent effects of different water types on oviposition in Aedes aegypti L. (Dipt., Culicidae). Journal of Applied Entomology, 127(1), 46-50.

Paraskeva, M. P., Van Vuuren, S. F., Van Zyl, R. L., Davids, H., \& Viljoen, A. M. (2008). The in vitro biological activity of selected South African Commiphora species. Journal of Ethnopharmacology, 119(3), 673-679.

Pereira, Á. I. S., Pereira, A. D. G. S., Sobrinho, O. P. L., Cantanhede, E. D. K. P., \& Siqueira, L. F. S. (2014). Atividade antimicrobiana no combate às larvas do mosquito Aedes aegypti: homogeneização dos óleos essenciais do linalol e eugenol. Educación química, 25(4), 446-449.

Rocha, M. M., Rodrigues, R. D. S., Guimarães, P. H. V., Gonçalves, J. K. M. da C. (2022). Larvicide potential of essential oils from Brazilian plants against Aedes aegypti. Research, Society and Development, 11(2), e53211226140.

Rüdiger, A. L., Siani, A. C., \& Junior, V. V. (2007). The chemistry and pharmacology of the South America genus Protium Burm. f.(Burseraceae). Pharmacognosy reviews, 1(1), 93-104.

Sampaio, E. V. S. B. (2002). Uso das plantas da caatinga. Sampaio, EVS B; Giulietti, A. M; Virgínio, J. \& Gamarra-Rojas, CFL Vegetação e flora da caatinga. Recife, 49-90.

Simas, N. K., Lima, E. D. C., Conceição, S. D. R., Kuster, R. M., Oliveira Filho, A. M. D., \& Lage, C. L. S. (2004). Produtos naturais para o controle da transmissão da dengue: atividade larvicida de Myroxylon balsamum (óleo vermelho) e de terpenóides e fenilpropanóides. Química nova, $27,46-49$.

Simões, C. (1999). SPITZER. V. Óleos voláteis. Simões, cmo, schenkel, ep, gosmann, g., mello, jcp, mentz, la, petrovick, pr Farmacognosia: da planta ao medicamento, 2, 387-415.

Silva, H. H. G., Silva, I. G. (1999). Influência do período de quiescência dos ovos sobre o ciclo de vida de Aedes aegypti (Linnaeus, 1762) (Diptera, Culicidae) em condições de laboratório. Rev Soc Bras Med Trop 32(4):349-55.

Silva, L. Á. D., \& Scariot, A. (2004). Composição e estrutura da comunidade arbórea de uma floresta estacional decidual sobre afloramento calcário no Brasil Central. Revista Árvore, 28, 69-75.

Shen, T., Li, G. H., Wang, X. N., \& Lou, H. X. (2012). The genus Commiphora: a review of its traditional uses, phytochemistry and pharmacology. Journal of ethnopharmacology, 142(2), 319-330.

Shulse, C. D., Semlitsch, R. D., \& Trauth, K. M. (2013). Mosquitofish dominate amphibian and invertebrate community development in experimental wetlands. Journal of Applied Ecology, 50(5), 1244-1256.

Souza, M. T. D., Silva, M. D. D., \& Carvalho, R. D. (2010). Revisão integrativa: o que é e como fazer. Einstein, 8, $102-106$. 
Research, Society and Development, v. 11, n. 3, e48611326680, 2022

(CC BY 4.0) | ISSN 2525-3409 | DOI: http://dx.doi.org/10.33448/rsd-v11i3.26680

Tomazzoni, M. I., Negrelle, R. R. B., \& Centa, M. D. L. (2006). Fitoterapia popular: a busca instrumental enquanto prática terapêuta. Texto \& ContextoEnfermagem, 15, 115-121.

Weeks, A., \& Simpson, B. B. (2007). Molecular phylogenetic analysis of Commiphora (Burseraceae) yields insight on the evolution and historical biogeography of an "impossible" genus. Molecular phylogenetics and evolution, 42(1), 62-79.

World Health Organization. (2004). WHO guidelines on safety monitoring of herbal medicines in pharmacovigilance systems. World Health Organization.

World Health Organization. (2012). WHO Weekly epidemiological record Relevé épidémiologique hebdomadaire. 